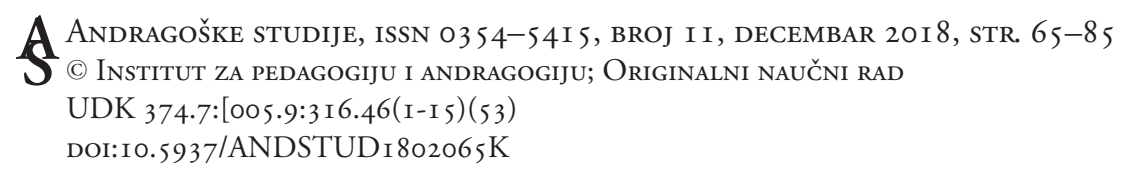

Amira Khattab ${ }^{1}$, David Wong ${ }^{2}$

Michigan State University, US

\title{
Integrating Western and Arab Leadership Development Practices: An Example of the Challenge Bridging Global and Local Adult Learning Perspectives
}

\begin{abstract}
In response to an insufficiently skilled labor force, Arab countries are looking to Western adult learning perspectives. However, Western practices cannot be implemented without consideration of regional culture. This large-scale study aims to identify best leadership development practices for Arab adult learners and examines how these practices might best fit with local cultural contexts. To determine the effective practices for Arab leaders, the Delphi process was utilized to survey 24 experts in the field of executive education. In addition, eight experts were interviewed and 1,500 business leaders from 17 different countries were surveyed. Hierarchical Linear Modeling (HLM) was used to examine indices for individual level relationships, as well as country level relationships. Findings suggest several implications for adult learning and leadership development - a key component to the success of the UN 2030 SDG project. First, adult learning practices must be 'customized' to address the tension between global and local perspectives. Second, the degree to which learners have experienced Western practices is important to know beforehand. Lastly, it is important to consider the group's "homogenizing" tendency where their traditional schooling experiences may foster deep resistance to outside, unfamiliar people, ideas, and practices.
\end{abstract}

Key words: national culture, adult learning, leadership development.

Bridging the gap between global (Western) and local (Arab) adult learning perspectives is key to the implementation of the United Nations' Sustainable Devel-

\footnotetext{
${ }^{1}$ Amira Khattab, PhD received her PhD in education, psychology and technology from Michigan State University, US. She advises the private and public sectors on strategy and solutions that foster human capital development (amira.khattab@darkmatter.ae).

2 David Wong, PhD is associate professor in College of Education, Michigan State University, US (dwong@ msu.edu).
} 
opment Goals (S.D.G.). For example, the SDG 4-Education 2030 aims at: (1) promoting cultural diversity, interconnectedness, peace and global citizenship as per Target 4.7, and (2) instilling relevant, transferable and entrepreneurial skills as per Target 4.4 (Rieckmann, 2017). These ambitious goals identify competencies and skills adult learners, universally, should aspire to as responsible citizens and productive workers. The challenge the Arab world faces is translating these global commitments within its local educational systems, particularly, among its leadership development programs.

With the strenuous, volatile forces shaping the Middle East and North Africa (MENA) region, the Arab world needs outstanding leaders able to take their people to more secure environments in the years to come (Jreisat, 2009) and take advantage of the opportunities that lie ahead (e.g., progressive political and economic reforms in KSA and advanced technological and innovation ecosystems in the UAE). In response, this study seeks to accelerate the development of Arab leaders and unpack effective ways to build a cohort of outstanding executives able to move their team, organizations, and societies toward a productive, fair, and stable future across both public and private sectors.

In spite of governments' substantial investment in the development of its human capital, the Arab region still suffers from a skills gap crisis. The majority of Arab countries score low in global ranks on education. Results from the OECD Programme for International Student Assessment (PISA) indicate the lower quality of learning in the region's schooling system compared to countries at similar income levels. According to the Shanghai Academic Ranking of World Universities, only five institutions in the Arab region made it to the list of the top 500 universities in the world. Furthermore, the region is afflicted by the persistent gap between the skills acquired at universities and the requirements of the labor market.

In oil-rich countries such as the Arab Gulf nations (GCC), many young people aim for conformity and comfortable jobs by joining the public sector, rather than pursue innovation and entrepreneurship within the more dynamic private sector. In turn, the private sector has relied on low-wage foreign workers to produce goods and services targeted mostly to the domestic market as opposed to the riskier, yet economically crucial, export market. This has favored the nontradable sector such as services and construction at the expense of high value-added tradable sectors with large spillover effects. As a result, growth in productivity in the region has under-performed. For example, productivity growth in the UAE has historically been stagnant, hovering around $0.2 \%$ per annum on average for the last two decades. In countries where economies are stagnant (typically in the Levant nations), rigid hiring and firing regulations are often associated with re- 
duced job opportunities, under-utilization of over-educated talent, and the brain drain. In addition, since family businesses constitute over $85 \%$ of the whole Arab non-oil GDP, staffing and recruitment rests heavily on personal connections, discouraging the pursuit of education.

Reform initiatives are underway looking to the West for best practices. Research highlights how approaches to learning vary across cultures and incongruity between modern (i.e., imported Western) pedagogical approaches and the traditional instruction typically found in the Arab classroom. Rather than simply importing Western models, there is a need to integrate Arabic and Western perspectives on leadership and approaches to learning. Against this backdrop, this study aims to identify best practices for leadership development by drawing on executive education experts in the MENA region, examine universal leadership practices against local cultural contexts, and investigate how learning and leadership approaches differ across Arab executives.

\section{Adult learning}

Adult learning and the related idea of lifelong learning have become important ideas in efforts to accelerate the upskilling of the local workforce and its leadership. The private and public sectors are now institutionalizing professional development programs and looking at Western perspectives of learning such as Andragogy and Self-Directed Learning (SDL). Knowles (1980) argues that the construct of andragogy highlights several distinctions between adult learning and K-12 and university learning: adults are capable of being self-directed, their preparedness to learn heavily depends on their social roles, adults seek to develop their current professional skills, and adults' life experiences enrich the content of what is being taught in the classroom. For this reason, if adult learners find that a learning experience - a professional development course, for instance - does not effectively address their needs, interests, or ways of learning, they will be much more likely to not participate or drop out than other learners.

Both Andragogy and SDL exist in stark contrast to Arabic learning traditions where individual autonomy is regarded as potentially damaging to the development of individuals and their relationship to others (Alshebou, 2010). Al-Harthi (2010) found cultural variations between Arab and American distance adult learners enrolled in online courses from the Arab Open University (AOU). American students scored higher than Arab students on key competencies needed to succeed in an online environment: planning, monitoring, effort, time and environment management, and self-efficacy. In contrast, Arab students preferred 
significantly higher structure and engagement with their instructors than American students. This may be related to Arab learners' reliance on instructor guidance as their source of wisdom and inclination to value being part of a group rather than functioning independently from others.

In this research project, we seek to highlight the incongruence between Western and non-Western perspectives and consider how professional development programs can be effectively designed to bridge the gap between local cultures and global standards.

\section{Leadership development}

Executive education specialists are encouraged to avoid adopting a universal approach to leadership models (e.g., Goldstein \& Ford, 2001; London, 2002; Hrivnak, Reichard \& Riggio, 2009). Instead, educators need to assess learners' prior knowledge and customize the program's content accordingly. Also, experiential learning approaches are commonly recommended, where learners learn by doing, rather than listening or reading, about something. In leadership training, experiential learning enables leaders to focus on both "individual and collective learning as they work on the projects, often guided by a coach who encourages reflection, dialogue, and feedback" (McCauley, 2008, p. 42). The instructor's role is to facilitate the construction of knowledge, build on adult learners' prior experience, and value participants' voices. The facilitator engages adults in real life scenarios, builds trust, and gives constructive feedback on the learning process in a timely manner (Fenwick, 2001).

To promote participation and retention levels in leadership development programs, it is critical to understand why adults partake in learning and why many do not. Based on Houle's (1961) typology, which has been tested over a large set of data and across several continents, adults are motivated to enroll in educational interventions for three main reasons: (a) to achieve a goal (e.g., career advancement), (b) to socialize and build connections with other adults, and (c) to satisfy the curiosity of the mind (e.g., learning for the sake of learning). Furthermore, Merriam, Caffarella \& Baumgartner (2007) assert that the two most common reasons for non-participation are lack of time and lack of money.

With regards to the leadership competencies taught in leadership programs, leadership models are largely based on progressive Western business values. The models emphasize ethics such as "transparency, accountability, consultation, tolerance and equity" (Neal \& Finlay, 2015, p. 39). In addition, Western theories of leadership emphasize trait theory, path-goal theory, team leadership theory, servant leadership, transformational leadership, and transactional and authentic 
leadership (Mameli, 2013). Research on executive education in the Arab world suggests that leadership models overlap with Western best practices reinforcing trait, transcendental, and ethical leadership theories (also found in many Islamic ideals). Effective leaders were found to possess (a) qualities that include personal, emotional and ethical dimensions (Kader, 1973), (b) specific skills/competencies, and (c) spiritual characteristics and closeness to God. In regards to ideal leadership qualities, scholars underscore the importance of humbleness, honesty, selfless service, conflict avoidance, balance, and charisma. The prophet Muhammad PBUH (peace by upon him) is considered a role model for leaders to follow.

Management training in the Arab world emphasizes apprenticeship, the development of a holistic mindset, storytelling, high Arabic literacy, job rotation, on-the-job training, and mentorship. Instructors are expected to take responsibility and control over the learning process, direct the flow of communication, and act as the source of wisdom in the classroom. Training for adult learners typically mirrors the traditional instructional approach found in Arabic schools. Wilkins (2001) showed the influence of religion, localization of case studies and Arabization of content in promoting the effectiveness of leadership development instruction. Adults typically use education as an enabler for fuller participation in the community (Al-Barwani \& Kelly, 1985) and to advance up the career ladder. Unfortunately, they also found the most common reason cited by Omari women for dropping out was the challenge of balancing between home responsibilities and studies, as well as program-related reasons (i.e., the difficulty of the content, fear of failure in assessments, and inconvenience of schedule).

\section{Executives' backgrounds}

According to Merriam, Caffarella \& Baumgartner (2007), learning and knowing are deeply intertwined with learner characteristics and cultural beliefs. As such, it is important to consider the adult learner's national cultural and geographical cultural background.

Culture is defined by King (2002, p. 89) as "a sense of peoplehood and commonality derived from kinship patterns, a shared historical past, common experiences, religious affiliations, language or linguistic commonalities, shared values, attitudes and perceptions, modes of expression and identity." Hofstede's cultural dimensions typology is the most commonly used to conduct cross-cultural research and to study the impact of culture on business management development.

In this study, we use Hofstede's (2001) Power Distance Index (PDI): a measure of the extent to which the less powerful members of organizations within 
a country expect and accept that power is distributed unequally. The higher the index, the more paternalistic a society is. These individuals accept prevalent hierarchy and do not challenge authority. We also use Hofstede's Uncertainty Avoidance Index (UAI): a measure of the extent to which the members of a culture feel threatened by uncertain or unknown situations.

These measures allow us to better understand how societies approach learning and leadership. To illustrate, Singapore scores relatively high on the PDI, reflecting a society where managers rely on their superiors and on set rules, and do not question either. Teachers in Asian countries are typically not challenged as they represent the source of wisdom in the classroom. The United Kingdom scores relatively low on the UAI, reflecting a curious nation with a strong need for innovation. Students are encouraged to be inquisitive and curricula include open ended assignments that examine multiple perspectives. Conversely, nations with high UAI are inclined to consider differences as dangerous: they tend to resist change and prefer to work on tasks with sure outcomes. Yamazaki's (2005) meta-analysis of four empirical studies (Boyatzis \& Mainemelis, 2000; Yamazaki \& Kayes, 2005; McMurray, 1998; Kolb \& Fry, 1975) highlights how learning approaches change with cultural differences and proposes ways management development training needs to adapt.

Through the geographical cultural lenses, groups living in different regions across the Arab world are impacted by powerful forces of integration such as religion, linguistic, political, socio-economic and ethnic affiliations. Those forces enable the Middle East and North Africa (MENA) region to portray two distinct sets of visible cultural norms and practices. The MENA Asia or Levant (Lebanon, Jordan, Iraq, and Syria) and MENA Gulf (United Arab Emirates, Bahrain, Kuwait, Oman, Qatar, Saudi Arabia, and Yemen) differ in levels of democratization, religious diversity, and natural resources. Countries in the Levant are labor abundant, resource-constrained, more pronounced religious diversity, and service-based economies. Gulf countries are labor-constrained, commodity rich countries with a homogenous population of Muslims (Ralston et al. 2009; 2012). We expect the dissimilarities between those two regions to affect management practices and the way their executives learn.

It is therefore vital for this study to investigate how national and regional cultural differences may be able to explain the variance in approaches to learning and leadership models. Culture is examined from both perspectives: national values as operationalized by Hofstede and regional differences based on geographical clustering. In addition, the educational background of executives will be examined to explore whether there will be differences in approaches to learning and leadership between those who have been exposed to an Arab curriculum versus 
those who have attended schooling built on Western curricula. Existing research that addresses the relationship between executives' education background and learning preferences is scarce.

\section{Research questions}

The larger goal of this research is to propose a model for an effective leadership development program for Arab professionals. In order to do this, this study first examines the most effective Arab leadership development practices as identified by business and international management experts. Then, this study explores the relationship between culture and learning preferences of Arab leaders. Culture is considered at two levels: national values as defined by Hofstede (2010) and geographical regions. Learning preferences include Arab's views on various aspects of leadership development curricula, instructional methodologies, leadership competencies, motivation enablers, perceived barriers, instructors' qualities and learning environment. This study addresses three research questions:

1. What are the most effective Arab leadership development practices as identified by experts?

2. How do cultural dimensions and geographical regional differences relate to learning preferences of Arab leaders, particularly to their views about central aspects of leadership development programs?

3. How do learner characteristics (i.e. gender, sector, age, and education background) relate to Arab preferences for leadership development?

\section{Method}

\section{Participants}

The Experts

A panel of experts in executive education participated in three rounds of surveys to identify the most important elements of leadership development programs. This process, also called the Delphi procedure (Linstone \& Turoff, 1975), used a stratified random sampling to select the expert panel that represented a diverse, high-level perspective on Arab leadership development. Experts included CEOs, $\mathrm{CAOs}$, research directors, university provosts, heads of NGOs, and government officials working across industries. Panel members averaged 20 years of experience in leadership development. 


\section{The Focus Group}

In order to shed further light of the results of the Delphi process, interviews were conducted with members of a focus group. The focus group consisted of eight Arab industry and academic leaders with extensive experience in executive education and seniority in their fields, and from across MENA region and the public and private sectors.

\section{The Executives}

The third source of data was executives working in public and private sectors from the MENA Gulf and Levant regions. A total of 837 executives responded to the survey. Figure 1 shows which nations are represented and the number of participants from each nation.

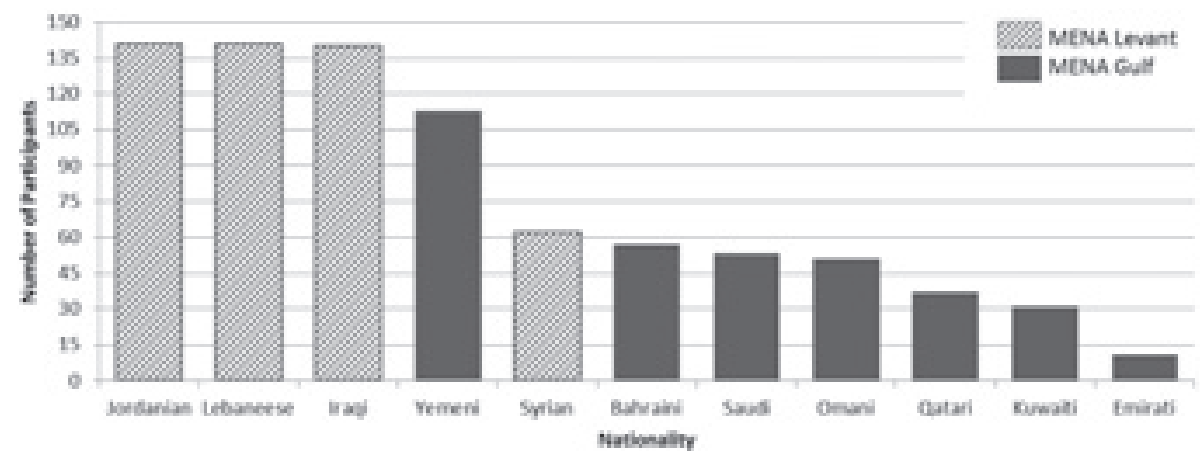

Figure 1: Participants by Nationality

\section{Materials}

\section{The Delphi Procedure}

The purpose of the Delphi procedure was to determine the experts' views on four areas of leadership development programs: methods of leadership development, content to be included in leadership development, motivational factors affecting participation, and barriers to participation. The Delphi Method included a group of expert participants, a moderator, three rounds of survey questions, and anonymous and independent participation. The Delphi surveys resulted in generating 174 items capturing best-practices for classroom-based leadership development 
programs. The Delphi process prioritized 50 items that formed the basis of the Large-Scale Survey (LSS).

\section{Face-to-Face Interviews}

An interview guide was used to identify the questions and the general guidelines for what the researcher should discuss throughout the interview session. The interviewee was asked to (a) review and elaborate on the highest and lowest rated items from the Delphi process, (b) identify gaps that were not raised in the Delphi process, and (c) discuss whether answers would change across nationalities, generations, and gender.

\section{The Large Scale Survey (LSS)}

The LSS was administered to Arab executives to learn about their views in response to the best practices identified by the Delphi experts and the focus group. Out of the 115 items used in the LSS, 74 items were grouped into seven scales to form constructs of the learning preferences related to various aspects of leadership development. Thirteen items were dedicated to demographic information and 28 items were from the Hofstede cultural module.

The dependent variable was characterized by six constructs: learning activities (LA), leadership competencies (LC), motivational enablers (ME), barriers to participation (BP), learning environment (LE), and instructor's characteristics (IC). Arab executives were asked to rate how important the items identified by the Delphi experts are to Arab executives. In summary, the Delphi Process indicated the desirable practices valued by the experts, whereas the LSS desired practices of the executives.

The LSS also included items for the homogeneity index (HO), an independent variable elaborated on in the discussion section. The LSS also gather data on executive's geographical area, nationality, and demographics (gender, educational background, sector, and age). Finally, the LSS contained items assessing two of Hofstede's cultural dimensions (PDI and UAI).

\section{Results}

Research Question 1: Effective Arab Leadership Development Practices

The Delphi experts nominated 174 best practices to be adopted in leadership development programs. These practices were qualitatively classified as univer- 
sal/Western or local. Analysis revealed $80 \%$ of the expert desirable features of a leadership program mirrors Western practices; 20\% represented Arabic (local) practices emphasized in the Quran, Arabic English language scholarship articles, and Arabic language publications focused on leadership in the Arab world.

Figure 2 illustrates the top ten most important items related to Learning Activities. Most items reinforce experiential learning strategies common in Western literature (e.g., "case studies" and "collaborative problem solving of real problems"). However, there was also an emphasis on social interaction, and more opportunities to talk and less reading material. This emphasis on dialogue and interaction is emphasized in Western approaches. However, these activities also have a strong connection to Arab tradition. Oral debates and theory building are well-known practices called munatharah in Islam, where individuals orally tackle local problems by introducing their perspectives and commenting on the strength and weaknesses of each solution as a collective unit (Ali, 1996). Finally, the list of highest rated practices points to the importance connecting to the Arabic context.

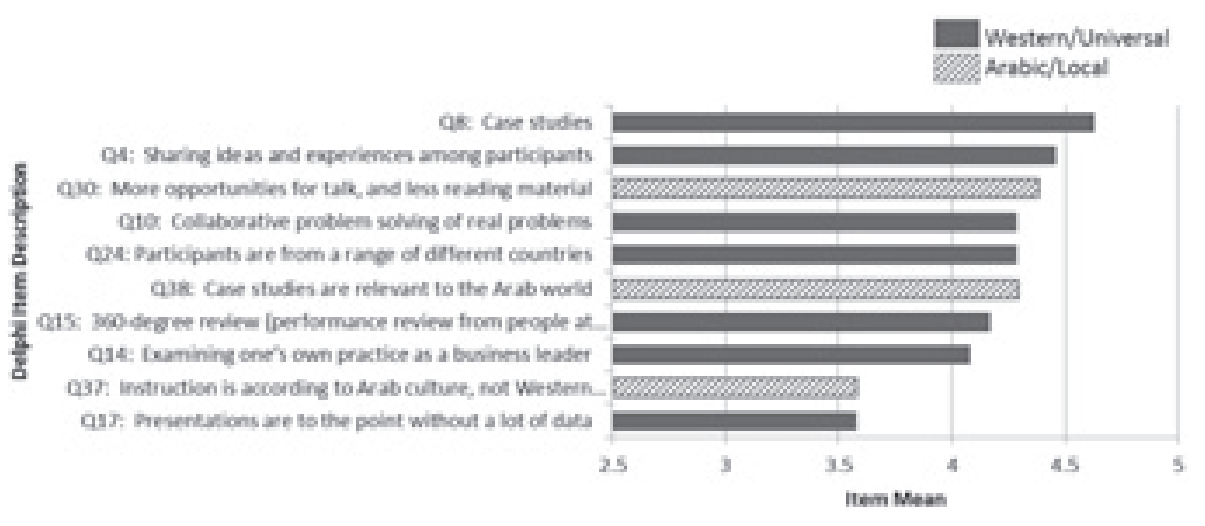

Figure 2: Delphi Experts' Selected Item Means for Learning Activities

Research Question 2: Regional \& Nationality Differences in Learning Preferences The Effects of Regional Differences

The HLM analysis, summarized in Table 1, indicates statistically significant differences between the Levant and Gulf regions. For example, executives in the Levant tend to rate learning activities 0.19 points higher than those in the Gulf $\left(\gamma_{01}=0.19 ; \mathrm{p}\right.$-value $\left.<0.01\right)$, when holding PDI and UAI scores constant. Also, ex- 
ecutives in the Levant region agreed with the experts' panel ratings more consistently than their counterparts in the MENA Gulf region. In contrast, respondents from the Gulf countries placed higher emphasis on teacher-centered education. Typical of Arab schools, teachers are viewed as the sole source of expertise who transfer knowledge to learners who do not challenge their authority. Not surprisingly, GCC executives were more skeptical of Western models of leadership. They were significantly more inclined to identify loyalty, ethics, personal relationships, status, and hierarchy as qualities of good leadership.

\section{The Effects of National Cultural Differences}

HLM results for both PDI and UAI were statistically significant across five of the six dependent variables, as presented in Table 1 . More specifically, as either the PDI or UAI score increases, the scores on the learning activities decreases. For example, if a country's PDI score increases by one point, then the learning activities score decreases by about 0.004 points $(\gamma 02=-0.004$; $\mathrm{p}$-value $<.05)$ when holding region and UAI scores constant. Similarly, if a country's UAI score increases by one point, then the leadership competencies score decreases by about 0.01 points $(\gamma 03=-0.01 ; \mathrm{p}$-value $<.05)$ when holding region and PDI scores constant.

Table 1: HLM Results

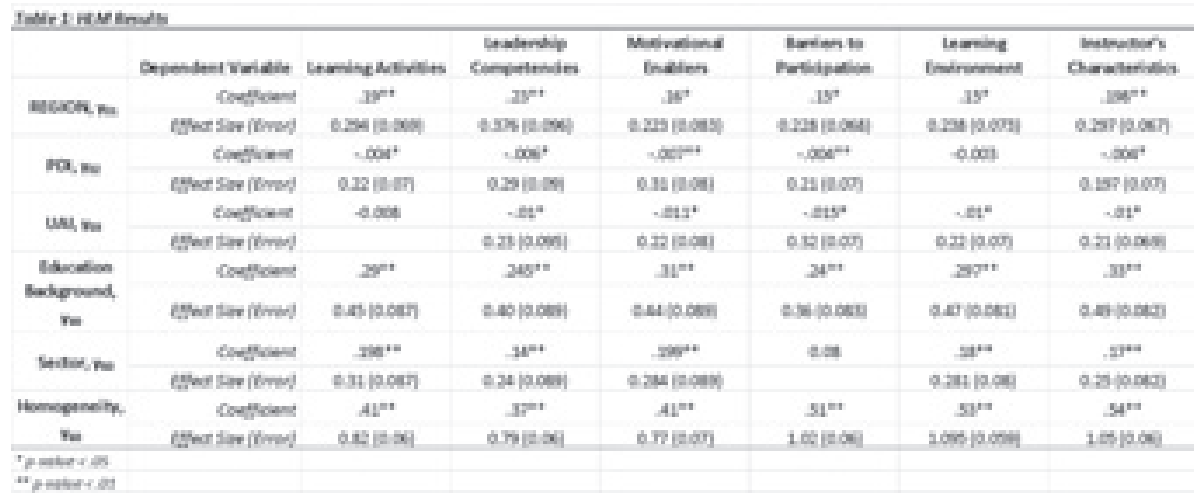

In general, executives from countries with stronger beliefs in hierarchical and unequal power dynamics (high PDI), as well as executives from nations with low tolerance for uncertainties (high UAI), agreed less with the Delphi experts on the importance of several aspects related to leadership development. Higher values of PDI and UAI were related to an inclination towards didactic approaches 
of learning, autocratic models of leadership, lecture or theory based teaching and traditional views for physical learning spaces and classroom tools.

Research Question 3: Demographic Differences Learning Preferences

Education Background

As shown in Table 1, all dependent variables have a statistically significant difference between executives' education background. For example, those with a Western/mixed high school education rated learning activities 0.29 points higher on average than those with a full Arabic education background $\left(\gamma_{30}=\right.$ 0.29 ; p-value $<0.01$ ), when holding other variables constant. While looking at the specific item mean differences within each construct, as shown in Figure 3, it can be seen that executives with Western/mixed high school education scored higher on all constructs except on the homogeneity (HO) construct (which has an overall construct mean difference of -0.2 ). This suggests that executives with Arabic educational backgrounds tended to agree more positively with experts when it comes to cultural congruence (e.g., items such as "instructor is Arab," "participants are all Arabs," and "materials provided in Arabic language"), and less positively with experts when it comes to the other learning and leadership preferences.

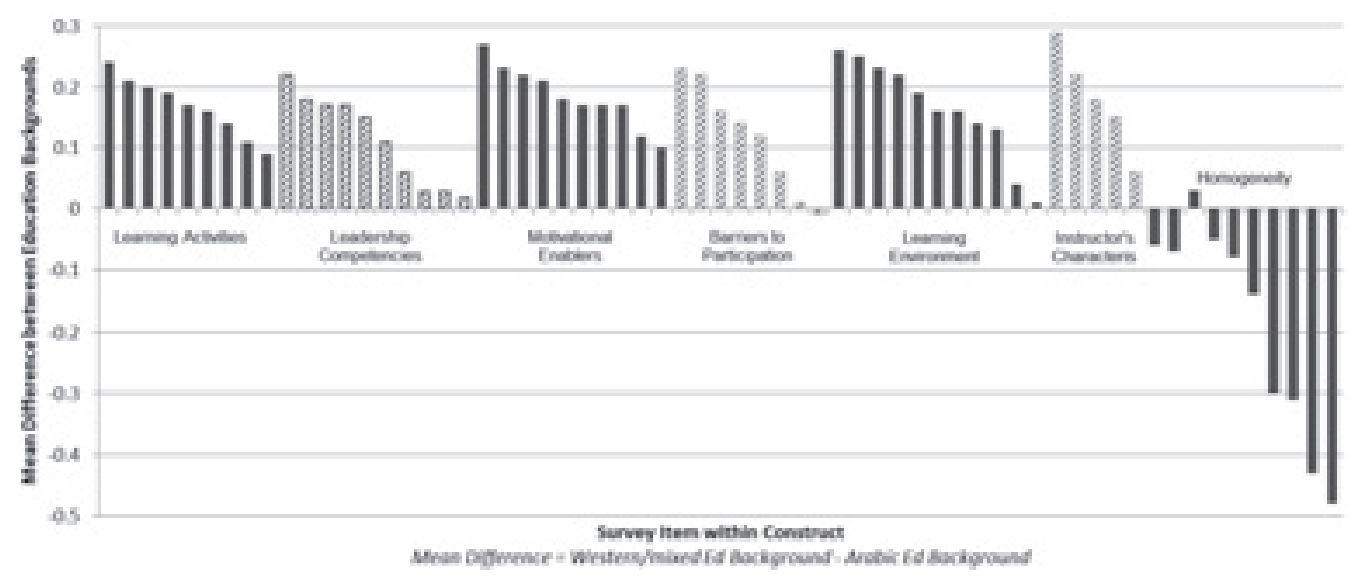

Figure 3: Item Mean Difference by Education Background (Items Grouped by Constructs) 


\section{Sector}

All constructs (except BP) have a statistically significant difference between both sectors (public and private). Executives working in the private sector tend to rate learning activities 0.198 points higher than those working in the public sector $\left(\gamma_{50}=0.198\right.$; $p$-value $\left.<0.01\right)$, when holding other variables constant. This difference between sectors shows that the executives working in the private sector generally have a higher agreement level with the best practices identified by the Delphi experts than executives who are working in the public sector or in NGOs.

\section{Homogeneity}

The homogeneity index captures executives' preferences to work with colleagues who are the similar to them: similar in terms of gender and tribal/nationality affiliation. Homogeneity, or cultural congruence, was statistically significant for all dependent variables. The HLM results in Table 1 show that when HO's score increases by one point, the learning activities score decreases by 0.41 points $\left(\gamma_{60}=0.41 ; \mathrm{p}\right.$-value $\left.<0.001\right)$ when holding other variables constant, with the largest effect size of 0.93 compared to all the independent variables tested. Surprisingly, executives with higher $\mathrm{HO}$ also agreed with the Delphi experts more than executives with lower homogeneity. This may suggest that $\mathrm{HO}$ is not in conflict with modern learning practices and leadership models. Instead, it may be a reflection of executives' attempt to protect the cultural identity of the Umma, while modernizing their organizations to foster growth and openness in a rapidly globalized world (Cook, 1999).

\section{Age and Gender}

Our executives were divided into three age groups: Millennials (34 and younger), GenX (35 to 49), and Veterans/Baby Boomers (50 and older). HLM results were not statistically significant for age and gender. Additional testing was conducted using the Kruskal-Wallis $\mathrm{H}$ test ${ }^{3}$. The results suggest that both Millennials and Gen X executives place high emphasis on the use of learning resources in leadership programs such as "materials accessible on the Web (virtual learning environment)". Veterans and Baby Boomers value leadership qualities such as "job-related competencies" more than the other two age groups. This indicates the tendency

\footnotetext{
3 The findings should only be suggestive or descriptive, as the Kruskal-Wallis $\mathrm{H}$ identifies the items where the groups are different, without controlling for nesting or other independent variables. Results should only be indicative of what may be important to attend to by leadership development designers.
} 
for the older generation to commend hard work and experience rather than just personality related leadership qualities (Rood, 2011; Kupperschmidt, 2000).

The results also suggest that compared to male executives, females place higher importance on several homogeneity items, as they are inclined to preserve cultural congruence in the classroom and believe that their leadership development faces higher cultural hurdles.

\section{Discussion}

Our study aims to identify best practices according to the beliefs of experts, associated with classroom-based professional development programs and examine the relationship between national culture (both values and geographical regions) and learning preferences of Arab executives. Existing literature suggests that approaches to learning vary across cultures and highlight the mismatch between modern (i.e., imported global) pedagogical models and traditional orientations to learning typically found in the Arab classroom. Yet research in the Arab world on adult learning is at a very early stage. To date, the limited number of studies still struggle to examine Arab adult learning approaches and how they vary across nationalities, geographical regions, educational background (Western vs. Arabic high school), sector, gender, and age.

\section{Culture Matters}

\section{Differences between Western and Arab Models}

Interestingly, $80 \%$ of the items mirror Western best practices, while only $20 \%$ is specific to the Arab context. The 80/20 ratio shows how both universal (e.g., ethical and relational leadership, entrepreneurial thinking, accountability) and local (high verbal interaction, fear of failure, reputational risks) factors can be integrated to design and deliver an effective professional leadership development program in the Arab region. As such, this study elaborates on similarities and differences to the West and ways educators can 'customize' learning to address the local context.

\section{Differences within the Arab World}

Findings show stark differences between Gulf and Levant executives' approaches to learning and leadership. Arabs are not only different from their Western counterparts but this study shows statistically significant differences between 
Arab regions. For example, Gulf countries exhibited a higher Power Distance Index (PDI) than Levant countries (refer to Figure 3). Typically, leaders from societies with a high PDI, are highly respected due to their positional power, and expect loyalty from their followers. In the workplace, leaders are viewed as a source of wisdom and make decisions on behalf of the team. Subordinates are encouraged to not contradict their managers and especially the elders. In the classroom, executives from countries with high PDI (e.g., Kuwait and KSA) tend to opt for teacher-centered education, where instructors take on the responsibility for the learning process and expected to initiate communication in the classroom.

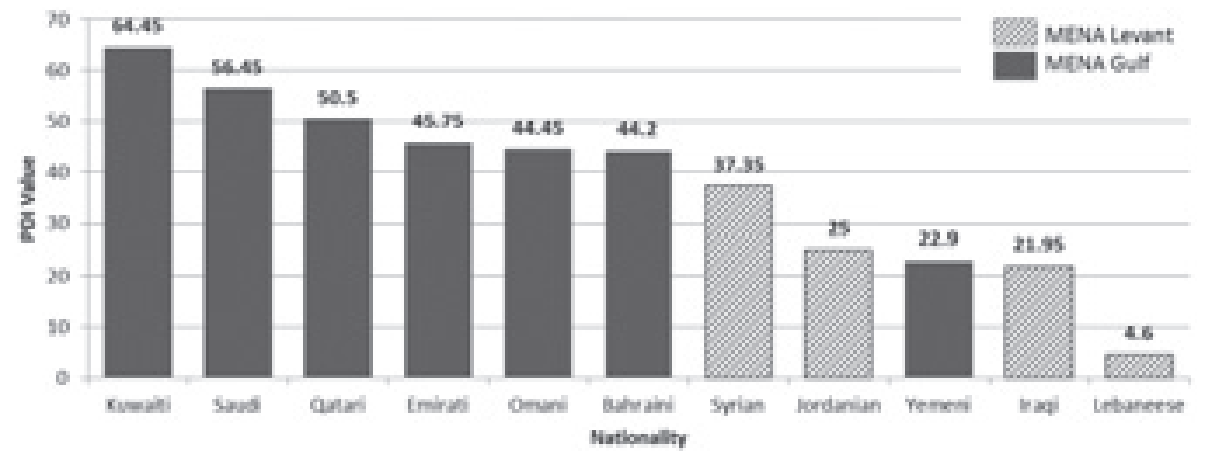

Figure 4: PDI Values of Arab Nations

\section{Differences between Educational Backgrounds}

Educational systems in the Arab world have been influenced by both an Islamic worldview and colonial secular approaches to learning. As such, schools in the Arab region either deliver a curriculum aligned with Western practices (i.e., modern, emphasizing experiential learning, self-directedness, and discovery) or dominated by a traditional approach to learning (i.e., didactic valuing authority, respect, and absolute truth). This study found that executives with Western or mixed educational backgrounds showed a higher inclination to adapt to modern leadership development approaches than those graduating from Arabic schooling. Executive education background has an average medium effect size of 0.43 , which is one of the most significant predictors to effective leadership. 


\section{Homogeneous Minds}

Culture was initially only operationalized using birth nationality and region; however, culture also manifested in the classroom as a set of unique preferences exhibited by executives. Arab executives expressed cultural preferences that preserve their individual identity by showing a high inclination to collaborate with peers of the same gender and nationality, study content that is delivered in Arabic language, learn from instructors with the same gender and nationality, analyze case studies that reflect the local context and even appoint senior leaders who are considered relatives or have a personal connection to in their organizations. Such an affinity to choose aspects of the leadership development program identical to executives' own gender, nationality, and in-group membership, was captured in the Homogeneity $(\mathrm{HO})$ construct. $\mathrm{HO}$, which neither has an equivalent in Western scholarship nor has been empirically examined by Arab studies, represents cultural congruence between executives and their preferred learning and leadership approaches. It indicates a preference for using instructional approaches attuned to the Arabic culture, incorporating the Arabic language and culturally relevant content in instruction, promoting leaders based on family and personal connections, encouraging the inclusion of participants and instructors with the same gender and nationality.

Interestingly, this study found that even though the majority of Gulf respondents agreed with the modern practices, they also scored high on the homogeneity preference. On one hand, many of the Gulf executives expressed their willingness to embrace modern practices, openness, and diverse points of view. On the other hand, their high score on the $\mathrm{HO}$ index or cultural congruence mirrored their tribal loyalty to identity and local roots. The tension between both modern and homogeneous preferences may need to be resolved should the Gulf executives aim to build a knowledge-based economy, which is underpinned by diversification, innovation and change.

The conceptual model in Figure 4 shows how region, national values, sector, educational background, and age relate to executives' learning preferences, noting the average effect sizes and positioning executives' responses within the continuum of high versus low agreement with the Delphi experts. Based on the model, addressing variability between those executives who agree with the experts and those who agree less with the experts requires a shift in beliefs, cultural norms, and practices that underpin learning and leadership. We recommend that this gradual shift is institutionalized during the schooling of future cohorts of leaders as change is a strenuous process that takes time. 


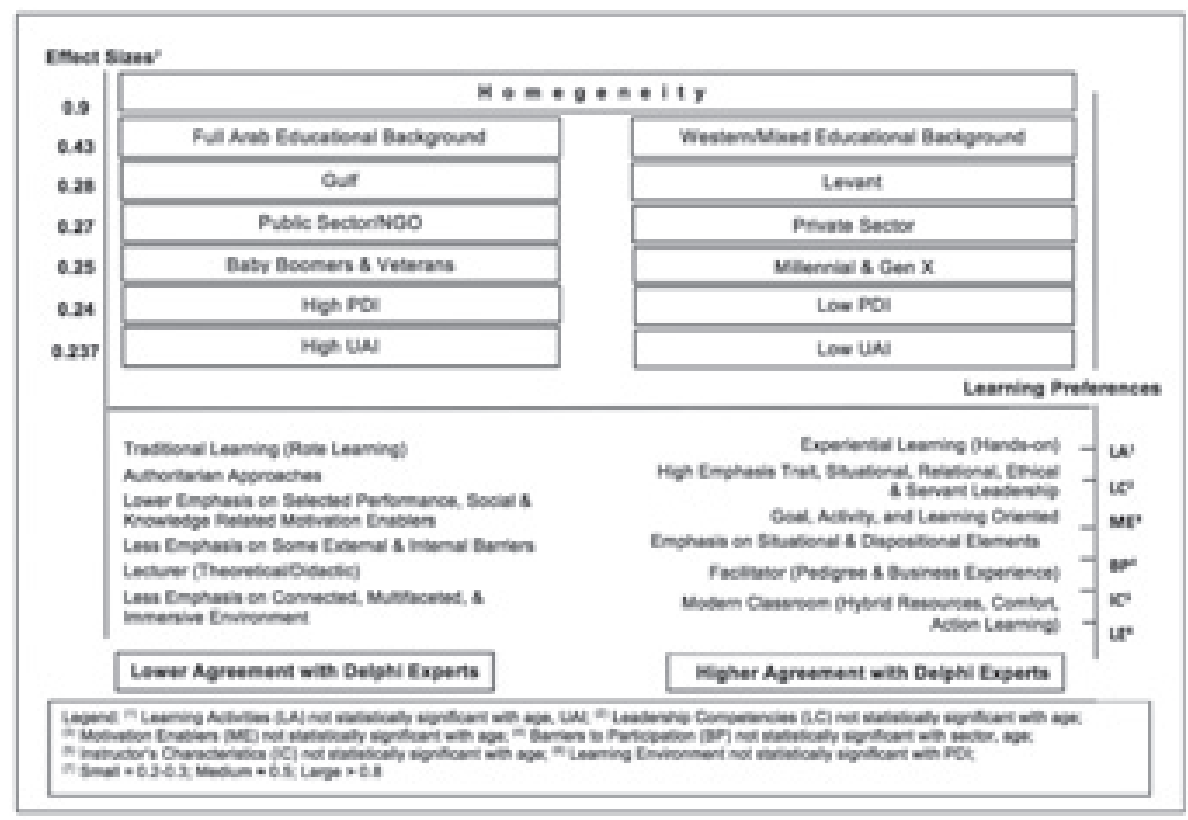

Figure 4: Conceptual Model Relating Executive Characteristics to Learning Preferences

\section{Limitations}

The design of this study is exploratory in nature and is based on observational data. Furthermore, the research only aimed at examining the desired learning and leadership practices of executives and the perceptions of what the experts view as desirable. It does not examine real behaviors of executives, which may be a more accurate measure of how they actually approach learning and apply leadership practices. Future research may investigate recommendations to test the effectiveness of the instructional methods and leadership models, which were nominated during the Delphi experts.

A third limitation to this study is the lack of psychometric information for the homogeneity index and the limited validity and reliability of the learning preference constructs. The multi-dimensional nature of the learning preference items suggests that the scales, when constructed, did not take into consideration the complex relationships that exist between items. Moreover, the survey 
scores may be limited by the effect of social desirability. Heine, Lehman, Peng \& Greenholtz (2002) contend that Americans tend to use more extreme values in their scoring, whereas Easterners are more inclined to use moderate points. Heine et al. (2002) argue that this inclination may be a result of culture, and that such bias may be reduced with certain types of items that measure concrete behaviors rather than ones that call for introspection. Another limitation is imposed by the HLM modelling procedure which assumes a linear relationship between variables. Lastly, caution should be taken when considering the PDI and UAI values of the UAE, as the sample size of the group was 11, which is smaller than the sample size recommended by Hofstede, Hofstede, Minkov \& Vinken (2008).

\section{Conclusion}

This study identifies best practices for classroom-based leadership development programs as per experts' views. It also informs theory that culture, regional differences, education background and norms can predict learning and leadership approaches of adult learners. Drawing on existing literature, $80 \%$ of the best practices recommended by the experts aligned with Western theories of learning and leadership and $20 \%$ were specific to Arabic scholarship. The majority of our executives were inclined to adopt modern best practices identified by the Delphi experts in spite of high levels of homogeneity. This suggests that Arab executives expressed preferences of openness to global standards, as well as an affinity towards local practices. Thus resonating with Nisbett's (2003, p. 228) claims that individuals who are exposed to Westernization and globalization, are inclined to becoming "bicultural" in response to blended social systems, interests, and values. Adult learning that values cultural diversity and effectively integrates global standards is a main outcome of this study and a principle goal for the UN2030 Agenda for Sustainable Development.

\section{Bibliography}

Al-Barwani T. \& Kelly, E. F. (1985). Factors influencing the recruitment and retention of literacy learners in Oman. International Review of Education, 31(2), 145-154.

Al-Harthi, A. S. (2010). Learner self-regulation in distance education: A cross-cultural study. American Journal of Distance Education, 24(3), 135-150.

Ali, A. J. (1996). Organizational development in the Arab world. Journal of Management Development, 15(5), 4-21. 
Alshebou, S. (2010). The benefits of adult learning: continuing education and the development process in the state of Kuwait. College Student Journal, 44(4).

Boyatzis, R. E., \& Mainemelis, C. (2000). An empirical study of the pluralism of learning and adaptive styles in an MBA program. Paper presented at The Annual Meeting of the Academy of Management: Management Education and Development Division, Toronto.

Соoк, B. (1999). Islamic versus west conceptions of education: Reflections on Egypt. International Review of Education, 45(3/4), 339-357.

FENwick, T. J. (2001). Experiential learning: A theoretical critique from five perspectives. Information Series No. 385. ERIC Clearinghouse on Adult, Career, and Vocational Education. Retrieved from http://eric.ed.gov/?id=ED454418

Goldstein, I. L., \& FORD, J. K., (2002). Training in organizations: Needs assessment, development, and evaluation. Belmont, CA: Wadsworth/Thomsen.

Heine, S. J., Lehman, D. R., Peng, K., \& Greenholtz, J. (2002). What's wrong with cross-cultural comparisons of subjective Likert scales? The reference-group effect. Journal of Personality and Social Psychology, 82(6), 903-918.

Hofstede, G. (2010). Geert Hofstede. National cultural dimensions.

Hofstede, G., (2001). Culture's consequences: Comparing values, behaviors, institutions and organizations across nations. Thousand Oaks, CA: Sage Publications.

Hofstede, G., Hofstede, G. J., \& Minkov, M., (2010). Cultures and organizations: Software of the mind. McGraw-Hill USA.

Hofstede, G., Hofstede, G. J., Minkov, M., \& Vinken, H. (2008). Announcing a new version of the Values Survey Module: The VSM 08. Retrieved from http:// stuwww.uvt.nl/ csmeets/VSM08.html

Houle, C. O. (1961). The inquiring mind. Madison: University of Wisconsin Press.

Hrivnak, G. A., Reichard, R. J., \& Riggio, R. E. (2009). A framework for leadership development. In S. Armstrong \& C. Fukami (Eds.). The Sage handbook of management learning, education and development (pp. 456-475). Thousand Oaks, CA: Sage.

Kader, A. A. (1973). Islamic leadership and personality from man to mankind. Al-Ittihad, 10(1), 9-10.

JREISAT, J. E. (2009). Administrative development in the Arab world: Impediments and future reform strategies. International Conference on Administrative Development: Towards Excellence in Public Sector Performance. Saudi Arabia, November 1-4. Retrieved from http://www.fifty.ipa.edu.sa/conf/customcontrols/paperworkflash/ Content/pdf/m3/en/3.pdf

Khatтab, A. (2015). How Arab Executives Learn. Michigan State University.

KInG, E. W. (2002). Ethnicity. In D. L. Levinson, P. W. Cookson, Jr., \& A. R. Sadowski (Eds.), Education and sociology: An encyclopedia (pp. 247-253). New York: Routledge Falmer.

Kolb, D. A., \& FRY, R. (1975). Toward an applied theory of experiential learning. In C. Cooper (Eds.). Theories of group processes (pp. 33-57). New York: Wiley. 
Knowles, M., (1980). The modern practice of adult education: From pedagogy to andragogy. New York: Cambridge Books.

Kupperschmidt, B. R. (2000). Multigeneration employees: Strategies for effective management. The Health Care Manager, 19(1), 65-76.

Linstone, H. A., \& Turoff, M. (1975). The Delphi method: Techniques and applications. Reading, MA: Addison-Wesley.

London, M. (2002). Leadership development: Paths to self-insight and professional growth. Mahwah, NJ: Erlbaum.

Mameli, P. (2013). Under new management: What the Arab Spring tells us about leadership needs in the Middle East and North Africa. Digest of Middle East Studies, 22(2), 377-404.

McCauley, C. D. (2008). Leader development: A review of research. Greensboro, NC: Center for Creative Leadership.

McMurray, D. (1998). Learning styles and organizational behavior in Japanese EFL classrooms. Journal of Fukui Prefecture University, 13, 29-43.

Merriam, S. B. \& Associates. (2007). Non-west perspectives on learning and knowing. Malabar, FL: Krieger.

Merriam, S. B., Caffarella, R. S., \& Baumgartner, L., (2007). Learning in adulthood: A comprehensive guide. San Francisco, CA: Jossey-Bass.

Neal, M., \& Finlay, J. L. (2008). American hegemony and business education in the Arab world. Journal of Management Education, 32(1), 38-83

NisbetT, R. E. (2003). The geography of thought: How Asians and Westerners think differently...and why. New York: Free Press.

Ralston, D. A., Egri, C. P., De la Garza Carranza, M. T., Ramburuth, P., Terpstra-Tong, J., Pekerti, A. A., ... Wallace, A. (2009). Ethical preferences for influencing superiors: A 41-society study. Journal of International Business Studies, 40(6), 1022-1045.

Ralston, D. A., Egri, C. P., Riddle, L., Butt, A., Dalgic, T., \& Brock, D. M. (2012). Managerial values in the greater Middle East: Similarities and differences across seven countries. International Business Review, 21(3), 480-492.

Rieckmann, M. (2017). Education for Sustainable Development Goals: Learning Objectives. UNESCO Publishing.

Rood, A. S. (2011). Understanding generational diversity in the workplace: What resorts can and are doing. Journal of Tourism Insights, 1(1), 79-89. http://dx.doi. org/10.9707/2328-0824.1009

Wilkins, S. (2001). Management development in the Arab Gulf states: The influence of language and culture. Industrial and Commercial Training, 33(7), 260-266.

YAMAZAKI, Y. (2005). Learning styles and typologies of cultural differences: A theoretical and empirical comparison. International Journal of Intercultural Relations, 29(5), $521-548$

YAmazAKI, Y., \& KaYes, D. C. (2005). Expatriate learning: Exploring how Japanese managers adapt in the United States. Paper presented at the Annual Meeting of the Academy of Management, Honolulu, Hawaii. 


\section{Integrisanje praksi za razvoj liderstva iz zapadnih i arapskih zemalja: primer izazova koji premošćava globalne i lokalne perspektive obrazovanja odraslih}

Apstrakt: Da bi odgovorile na problem neadekvatno kvalifikovane radne snage, arapske zemlje su počele da razmatraju perspektive obrazovanja odraslih osoba iz zapadnih zemalja. Međutim, prakse zapadnih zemalja ne mogu da se primene ukoliko se zanemari regionalna kultura. Ova opsežna studija nastoji da otkrije najbolje prakse za razvoj liderstva kod odraslih učenika u arapskim zemljama i ispituje kako te prakse mogu na najbolji način da se uklope u lokalni kulturni kontekst. Da bismo utvrdili efikasne prakse za arapske lidere, primenili smo Delfi metodu i ispitali 24 stručnjaka iz područja obrazovanja rukovodilaca. Osim toga, intervjuisali smo osam stručnjaka i ispitali 1.500 poslovnih lidera iz 17 različitih zemalja. Primenili smo hijerarhijsko linearno modelovanje (HLM) kako bismo istražili indekse odnosa na nivou pojedinaca, kao i na nivou zemlje. Utvrdili smo nekoliko implikacija za obrazovanje odraslih i razvoj liderstva, što su ključne komponente za uspešnost projekta „Ciljevi održivog razvoja“ u sklopu Agende UN do 2030. godine. Kao prvo, prakse obrazovanja odraslih moraju da budu "prilagođene“ da bi se umanjio raskorak između globalnih i lokalnih perspektiva. Kao drugo, važno je da se unapred ima u vidu izloženost učenika praksama zapadnih zemalja. Konačno, značajno je da se razmotri tendencija grupe za „homogenizovanjem“, to jest činjenica da njihovo prethodno iskustvo sa obrazovanjem može da prouzrokuje nastanak dubinskog otpora prema stranim elementima, nepoznatim osobama, idejama i praksama.

Ključne reči: nacionalna kultura, obrazovanje odraslih, razvoj liderstva.

\footnotetext{
${ }^{4}$ Dr Amira Khattab je doktorirala na Državnom univeritetu u Mičigenu, SAD. Ona je i konsultantkinja u privatnom i javnom sektoru u vezi sa strategijama i rešenjima koje unapređuju razvoj ljudskog kapitala.

${ }^{5}$ Dr David Wong je vandredni profesor na Koledžu za obrazovanje Državnog univerziteta u Mičigenu, SAD.
} 